\title{
PENGARUH FILM ANIMASI UPIN DAN IPIN TERHADAP PEMBENTUKAN SELF CONCEPT SISWA DI SDN 5 PADANGLAMPE KABUPATEN PANGKEP
}

\author{
Muhammad Saleh, Hayana, Iskandar \\ Institut Agama Islam Negeri (IAIN) Parepare \\ Email: Hayanaheart@gmail.com
}

\begin{abstract}
This study focuses on studying the meaning of the messages contained in the animated films Upin and Ipin and the influence of Upin and Ipin's animated films on the self concept formation of Padanglampe 5 Elementary School students. The purpose of this study was to find out the meaning of the message and the influence of Upin and Ipin animated films on the self concept formation of students at SDN 5 Padanglampe.

This research was carried out at SDN 5 Padanglampe kec. Ma'rang, Pangkep district. The research method used is the experimental research method (Research Experiment) with a quantitative approach. Experimental research aims to investigate the causal relationship by exposing one or more experimental groups.

The results showed that there were several scenes in the animated film Upin and Ipin which gave a labeling scene and the average labeling given was positive. The more often someone puts a positive word on someone else, then the person given the labeling has a positive self concept for him. Besides the results of the correlation test on students' self concept formation rxy $=0.644>r=$ table $=$ 0.361 then the hypothesis $\mathrm{HO}$ is rejected and $\mathrm{HI}$ is accepted. This means that $\mathrm{HI}$ is accepted, namely there is the influence of Upin and Ipin animated films on students' self concept at SDN 5 Padanglampe, Pangkep district.
\end{abstract}

Keywords: Influence, Upin and Ipin, Self concept, Students.

\section{PENDAHULUAN}

Perkembangan ilmu pengetahuan yang mengakibatkan perkembangan teknologi semakin meningkat menjadikan masyarakat selalu disuguhkan dengan berbagai informasi yang dapat memengaruhi kehidupan mereka. Salah satunya adalah dengan ditemukannya media massa yang dampaknya bisa memberikan dampak positif maupun negatif yang kemudian dalam ilmu komunikasi memunculkan pembahasan tentang komunikasi massa.

Apapun profesi atau pekerjaan seseorang, setidaknya ia pernah mendengarkan siaran radio, menonton televisi atau film, membaca koran atau majalah. Ketika seseorang mendengarkan siaran radio, membaca koran atau menonton film sebenarnya ia sedang berhadapan atau terterpa media massa di 
mana pesan media itu secara langsung atau tidak langsung tengah memengaruhinya. Gambaran ini mencerminkan bahwa komunikasi massa dengan berbagai bentuknya senantiasa menerpa manusia dan manusia senantiasa menerpakan dirinya kepada media massa. ${ }^{1}$ Kita bisa melihat di mana dalam kehidupan sehari-hari kita tidak bisa terlepas dari media massa entah itu media cetak maupun media elektronik dan salah satunya adalah film yang masuk dalam kategori media elektronik.

Kekuatan dan kemampuan film menjangkau banyak segmen sosial, lantas membuat para ahli bahwa film memiliki potensi untuk memengaruhi khalayaknya. $^{2}$

Dewasa ini banyak serial kartun yang ditayangkan di televisi dan disukai anak-anak. Namun tidak semua serial kartun pantas untuk disaksikan oleh anakanak karena banyak film kartun yang menampilkan adegan-adegan kekerasan, pornografi yang tidak layak untuk dikonsumsi oleh anak-anak. Berdasarkan laporan Yayasan Pengembangan Media Anak (YPMA) bahwa pada tahun 2005, rata-rata presentase film kartun dibandingkan tayangan anak lainnya adalah 72,09\%. Angka ini meningkat pada tahun 2006, yaitu 86,71\%. Namun tidak semua serial animasi atau biasa disebut dengan serial kartun yang ditayangkan di televisi menyuguhkan hal-hal negatif. ${ }^{3}$ Seperti salah satu film animasi yang diproduksi oleh Les Copaque "Upin dan Ipin” yang setiap harinya ditayangkan di MNC TV dapat menarik perhatian khususnya anak-anak.

Dari pengamatan sekilas, terkadang film Upin dan Ipin menjadi tiruan dalam berinteraksi terhadap satu sama lain khususnya di siswa-siswi SDN 5 Padanglampe. Seperti mencontoh gaya bicara dari film Upin dan Ipin ataupun siswa-siswi yang menggunakan perlengkapan sekolah seperti buku, tas, jam tangan atau benda lainnya yang bersimbolkan Upin dan Ipin selain itu terdapat

1 Elvinaro Ardianto, Lukiati Komala dan Siti Karlinah, Komunikasi Massa (Cet. IV, Bandung: Simbiosa Rekatama Media, 2014), h. 1

${ }^{2}$ Alex Sobur, Semiotika Komunikasi (Cet. III, Bandung: PT Remaja Rosdakarya, 2006), h. 127

${ }^{3}$ Vina Tri Hapsari, Naskah Publikasi: Pengaruh Intensitas Menonton Serial Animasi Upin dan Ipin Terhadap nilai-nilai moral, http://eprints.ums.ac.id/23061/9/Naskah_Publikasi.pdf (11 Oktober 2016) 
Hayana, Pengaruh Film Upin dan Ipin terhadap...

pula pola asuh yang ditampilkan oleh nenek (opah) Upin dan Ipin. Hal inilah yang dapat mempengaruhi self concept (konsep diri) anak sehingga peneliti tertarik untuk melakukan penelitian ini.

\section{PEMBAHASAN}

\section{Gambaran Umum Self Concept}

Masalah-masalah rumit yang dialami manusia, seringkali dan bahkan hampir semua sebenarnya berasal dari dalam diri. Mereka tanpa sadar menciptakan mata rantai masalah yang berakar dari problem konsep diri. Dengan kemampuan berpikir dan menilai, manusia malah suka manilai yang macammacam terhadap diri sendiri atau orang lain dan bahkan menyakini persepsinya yang belum tentu objektif. Dari situlah muncul problem seperti inferioritas, kurang percaya diri, dan hobi mengkritik diri sendiri. ${ }^{4}$ Misalnya jika seorang siswa yang memiliki kelemahan fisik yang mengurangi kepercayaan dirinya sehingga ia akan menilai dirinya secara negatif.

Rogers mengatakan bahwa konsep diri adalah kesadaran tentang diri yang mencakup semua gagasan, persepsi dan nilai yang menentukan karakteristik seseorang. Konsep diri mempunyai peranan penting dalam menentukan perilaku seseorang, bagaimana seseorang memandang dirinya yang akan tampak dari karakter dan seluruh perilakunya. Kesadaran dan pandangan tentang dirinya dihayati dan memengaruhi persepsi seseorang tentang kehidupan atau perilaku tersebut bersifat positif dan negatif, tergantung pada konsep diri yang positif maupun negatif dari seseorang tersebut.

Self Concept (konsep diri) dapat di definisikan secara umum sebagai keyakinan, pandangan atau penilaian seseorang terhadap dirinya. Definisi yang lebih perinci lagi adalah sebagai berikut: Konsep diri adalah keyakinan yang dimiliki oleh individu tentang atribut (ciri-ciri, sifat) yang dimiliki (Bhrem \& Kasim). Definisi lain menyebutkan bahwa konsep diri merupakan semua perasaan dan pemikiran seseorang mengenai dirinya sendiri. Self Concept meliputi

\footnotetext{
${ }^{4}$ Nina W. Syam, Psikologi Sosial Sebagai Akar Ilmu Komunikasi (Cet. II, Bandung: Simbiosa Rekatama Media, 2014), h. 55

${ }^{5}$ Herri Zan Pieter, Pengantar Komunikasi dan Konseling (Jakarta: Kencana Prenada Media Group), h. 159
} 
kemampuan, karakter diri, sikap, tujuan hidup, kebutuhan dan penampilan diri. ${ }^{6}$ Seperti dari beberapa item pertanyaan pada angket peneliti memasukkan pertanyaan tentang penampilan siswa ketika siswa pergi ke sekolah dan hasilnya beberapa dari siswa yang menjawab angket yang telah dibagikan memandang dirinya sebagai anak yang kurang rapi dalam berpakaian.

\section{Pentingnya Self Concept (Konsep Diri)}

Para teorisi yang melihat perilaku manusia berjalan mulus, konsisten dan terorganisasi dengan baik membutuhkan suatu konsep yang bertanggung jawab untuk karakteristik-karakteristik perilaku ini. Beberapa teori mempostulasikan diri sebagai agen pengorganisasian kepribadian. Sering juga diri dipostulasikan sebagai mekanisme yang menyediakan konsistensi individu di sejumlah waktu dan situasi. Teori-teori dari Horney, Allport dan Rogers mengandalkan betul konsep diri. Teorisi lain mengklaim bahwa penggunaan konsep diri sekadar mengganti semua pertanyaan yang kita miliki tentang seseorang menjadi pertanyaan tentang diri. Dengan kata lain, diri dilihat sebagai Homunkulus (yaitu istilah lama untuk individu kecil di dalam otak, penggambaran kuno tentang fungsi kepribadian) di dalam diri seseorang yang menyebabkan semua tindakannya. ${ }^{7}$ Misalnya seseorang siswa yang menilai dirinya itu adalah anak yang rajin dan pintar maka besar kemungkinan tindakannya akan rajin belajar di sekolah maupun rumah.

\section{Proses Pembentukan Self Concept}

Self Concept terbentuk melalui proses belajar sejak masa pertumbuhan seorang manusia dari kecil hingga dewasa. Lingkungan, pengalaman dan pola asuh orang tua turut memberikan pengaruh yang signifikan terhadap self concept yang terbentuk. Sikap atau respon orang tua dan lingkungan akan menjadi bahan informasi bagi anak untuk menilai siapa dirinya. Oleh karena itu, seringkali anak-

\footnotetext{
${ }^{6}$ Nina W. Syam, Psikologi Sosial Sebagai Akar Ilmu Komunikasi, h. 55

7 Matthew H. Olson dan B.R Hargenhahn, Pengantar Teori Kepribadian (Edisi ke-8, Yogyakarta: Pustaka Pelajar, 2013), h. 13
} 
Hayana, Pengaruh Film Upin dan Ipin terhadap...

anak yang tumbuh dan dibesarkan dalam polah asuh yang keliru dan negatif, atau lingkungan yang kurang mendukung, cenderung mempunyai konsep diri yang negatif. ${ }^{8}$ Lalu yang menjadi fenomena saat ini, banyak diantara orangtua yang tergantikan perannya oleh televisi. Anak-anak yang lebih banyak menghabiskan waktunya di depan televisi. Seperti di SDN 5 Padanglampe, ketika peneliti melakukan observasi banyak di antara siswa-siswi SDN 5 Padanglampe yang memiliki hobi menonton televisi khususnya tayangan animasi Upin dan Ipin. Selain itu pola asuh yang ditampilkan oleh keluarga Upin \& Ipin maupun interaksi yang dilakukan oleh Upin dan Ipin bersama teman-temannya yang apabila seseorang anak yang secara continue menerima terpaan dari media tersebut dapat memengaruhi pola pikir yang dapat berujung pada self concept sehingga dapat menghasilkan tindakan sesuai dengan keinginannya.

\section{Makna Pesan yang Terdapat dalam Film Animasi Upin dan Ipin}

Sebuah film tentu memiliki makna dalam setiap adegan. Penafsiran makna muncul dalam benak setiap penonton, diinterpretasikan sesuai dengan orientasi, kepentingan dan kompetensi mereka sendiri. Pemaknaan pesan peneliti menggunakan sebuah pendekatan semiotika merupakan upaya penggalian secara lebih mendalam.

Semiotika adalah suatu ilmu atau metode analisis untuk mengkaji tanda. Tanda-tanda adalah perangkat yang kita pakai dalam upaya berusaha mencari jalan di dunia ini, di tengah-tengah manusia dan bersama-sama manusia. Semiotika atau dalam istilah Barthes, semiologi, pada dasarnya hendak mempelajari bagaimana kemanusiaan (humanity) memaknai hal-hal (things). Memaknai (tosinify) dalam hal ini tidak dapat dicampuradukkan dengan mangkomunikasikan (to communicate). Memaknai berarti bahwa objek-objek tidak hanya membawa informasi, dalam hal mana objek-objek itu hendak berkomunikasi, tetapi juga mengkonstitusi system terstruktur dari tanda (Barthes). ${ }^{9}$

Untuk menjawab pertanyaan pada bagian rumusan masalah penelitian.

Peneliti mendapatkan dari dua sumber data, yakni data primer dan data sekunder.

Data primer diperoleh dari hasil observasi dengan menonton DVD/VCD film

\footnotetext{
${ }^{8}$ Nina W. Syam, Psikologi Sosial Sebagai Akar Ilmu Komunikasi, h. 56

${ }^{9}$ Alex Sobur, Semiotika Komunikasi (Cet. III, Bandung: PT Remaja Rosdakarya, 2006), h. 15
} 
animasi Upin dan Ipin, kemudian peneliti akan melakukan pengamatan secara menyeluruh secara teliti dan mendalam tiap shot per scene. Selanjutnya peneliti akan mengidentifikasikan dialog dan visual gambarnya yang dapat mewakili dan menggambarkan self Concept. Sedangkan data sekunder, data akan diperoleh melalui studi pustaka dengan membaca literatur, buku-buku bacaan dan tulisan ilmiah yang berkaitan dan relevan dengan objek penelitian yang diteliti.

Dengan banyaknya episode film Upin dan Ipin maka peneliti hanya memilih beberapa episode sesuai dengan relevansi dari objek penelitian. Maka peneliti memilih "Perangi Rasuah, Isi masa lapang, Usahawan Muda, dan Jembatan ilmu". Pemilihan episode ini sesuai dengan pernerpaan (penayangan) film pada kelompok B siswa SDN 5 Padanglampe.

Gambar: Pembuka (Intro) Film Animasi Upin dan Ipin
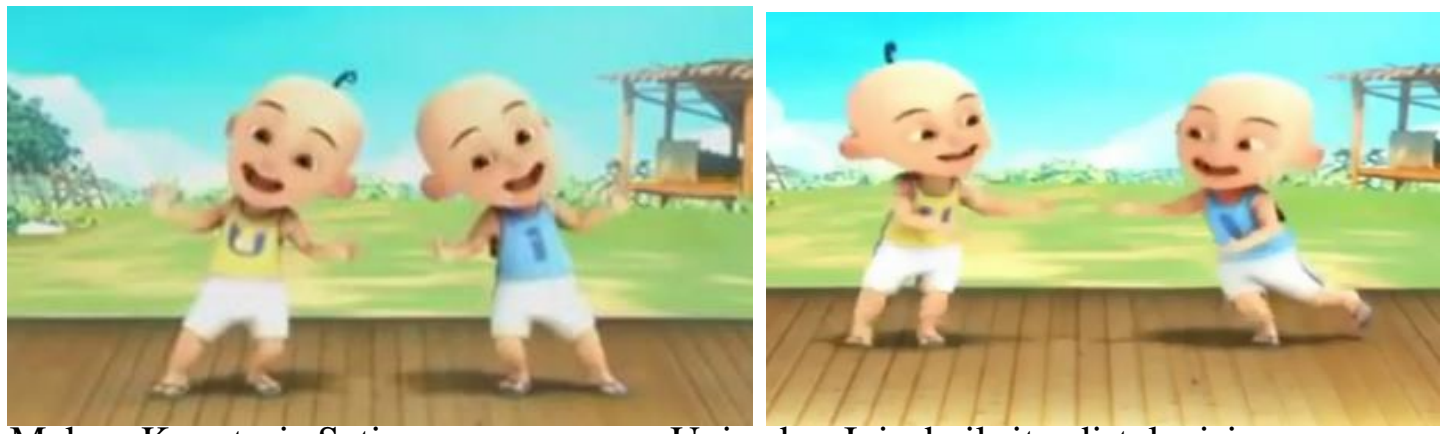

Makna Konotasi: Setiap penanyangan Upin dan Ipin baik itu di televisi maupun dalam bentuk DVD pihak film selalu menampilkan terlebih dahulu Upin dan Ipin yang bernyanyi dengan penuh ceria.

Representasi Pesan: Siswa yang setiap kali melihat tayangan pertama Upin dan Ipin ekspresi mereka langsung tersenyum. Dalam pandangan siswa Upin dan IPin merupakan sosok yang periang. Dengan ditampilkannya (penampilan pembuka) dengan nyanyian bersama disertai dengan wajah yang ceria penuh dengan senyuman. Selain adegan menyanyi juga disertai dengan goyangan Upin dan Ipin. Scene ini dapat memberi ransangan kepada anak-anak yang menonton bahwa kita harus selalu ceria, penuh tawa, dan jangan bersedih hati. Jika dihubungkan dengan 
self concept seseorang siswa akan memandang dirinya sebagai pribadi yang ceria dan ramah.

Scene yang lain yang menunjukkan bahwa Upin dan Ipin adalah anak yang ramah seperti gambar berikut ini:

Gambar: Pengenalan Identitas
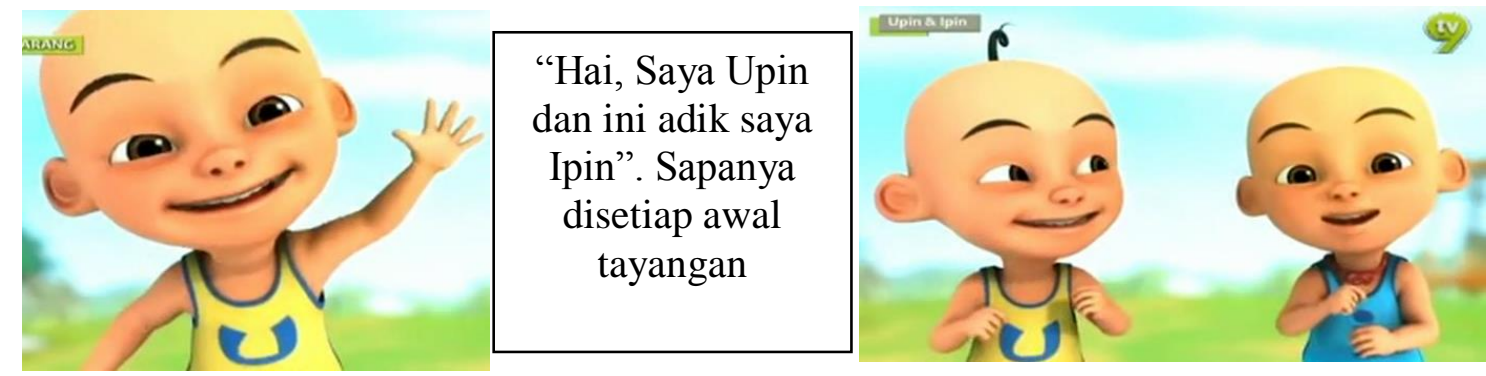

Pada episode Perangi rasuah seperti dalam gambar 4.3 dalam percakapan Atuk (kakek) menyebut Upin dan Ipin sebagai anak yang pandai karena Upin dan Ipin mampu menjelaskan kepada atuk dan yang lainnya terkait tentang apa itu rasuah. Rasuah merupakan episode yang membahas tentang bahaya suap menyuap yang dilarang di negara Malaysia seperti juga di Indonesia.

Gambar: Episode Perangi Perangi Rasuah
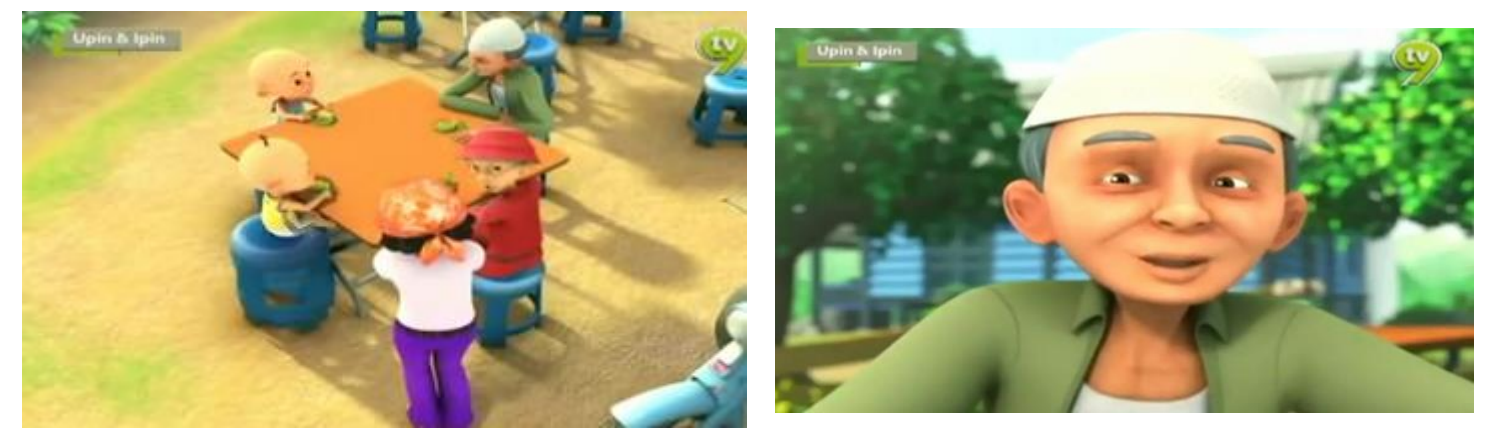

Pelabelan kata 'pandai' yang dilakukan oleh atuk kepada Upin dan Ipin dapat membangun self concept (konsep diri) pada diri Upin dan Ipin. Hal ini akan meningkatkan pandangan positif tentang citra diri mereka.

Mengapa demikian? Karena konsep diri yang dimiliki seseorang bukan bawaan dari lahir melainkan diperoleh dari belajar atau hasil interaksi dengan orang lain dan lingkungannya. Seseorang dapat belajar dengan baik bergaul dengan lingkungannya, penuh persahabatan dan ditunjang oleh lingkungan fisik 
maupun nonfisik, maka orang tersebut akan memiliki konsep diri yang positif, sehingga dapat melaksanakan fungsi dan tugas dirinya di lingkungan dengan baik. ${ }^{10}$ Jika self concept dapat diperoleh dari belajar, maka siswa-siswa SDN 5 Padanglampe yang di mana kesehariannya setelah pulang sekolah lebih suka menonton Upin dan Ipin maka kemungkinan ketika siswa memiliki intesitas yang tinggi dalam menonton film Upin dan Ipin mereka dapat belajar sesuatu hal dalam film tersebut. Seperti gambar 4.4 juga memberikan self concept positif kepada Mail ketika Fizi berkata "Pandailah kau Mail".

Dalam benak siswa kata 'pandai' merupakan orang yang pintar atau mampu melakukan atau menjelaskan terhadap sesuatu hal dan tidak semua orang mempunyai kemampuan seperti ini. Di lingkup siswa seseorang dikatakan 'pandai' jika ia mampu mendapatkan nilai-nilai yang memuaskan dari guru atau mampu menjawab soal-soal yang diberikan di dalam aktivitas proses belajar maupun menang dalam sebuah pertandingan (lomba).

Gambar: Episode Perangi Rasuah

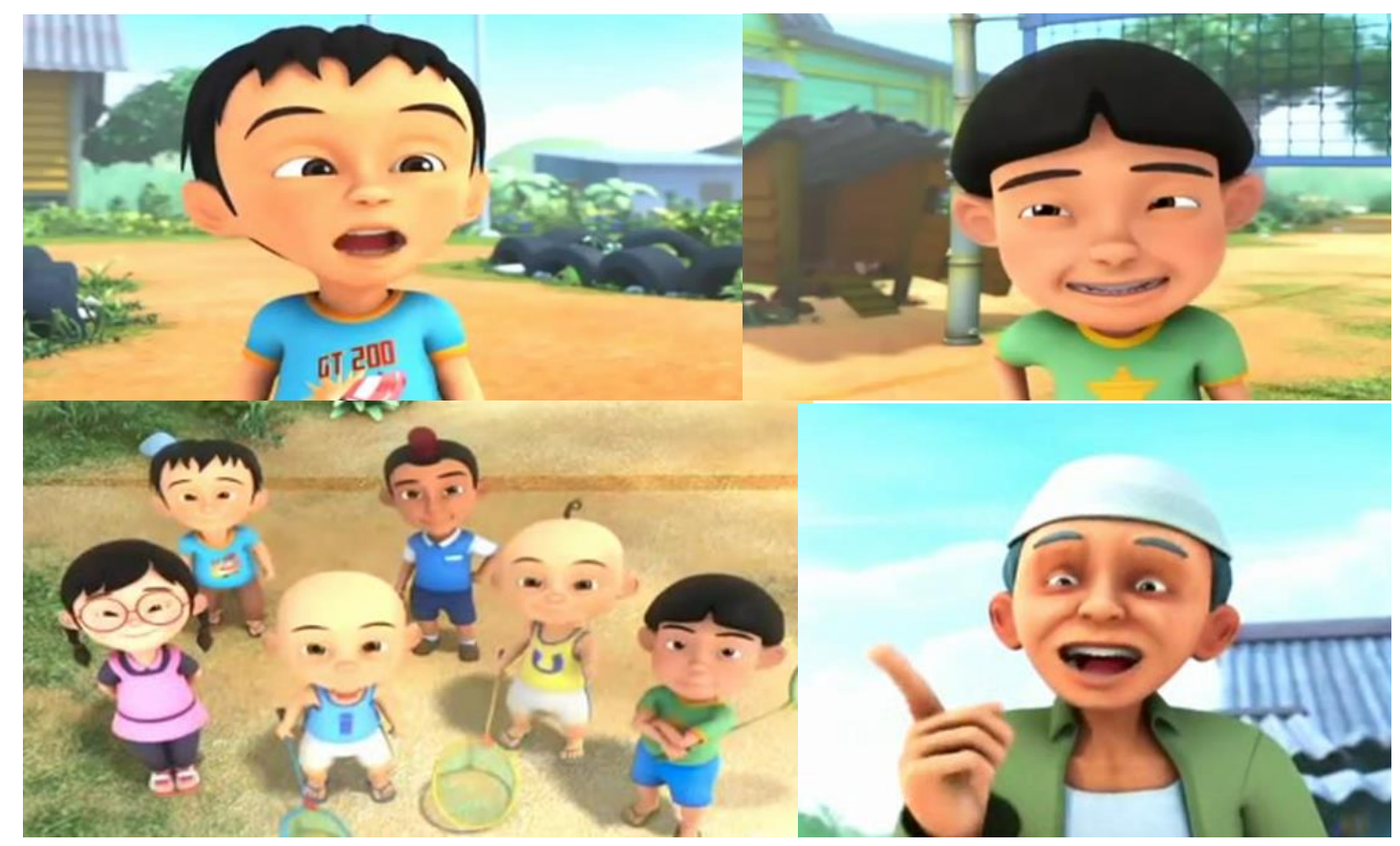

${ }^{10}$ Herri Zan Pieter, Pengantar Komunikasi dan Konseling , h. 157 
Hayana, Pengaruh Film Upin dan Ipin terhadap...

Untuk kedua kalinya atuk memberi pelabelan kata 'pandai' kepada Upin dan Ipin beserta kawan-kawannya seperti pada gambar 4.4. memang dalam film animasi Upin dan Ipin pelabelan yang dilakukan lebih banyak menggunakan kata pandai. Hal ini menunjukkan bahwa pihak penulis skenario film Upin dan Ipin ingin menunjukkan atau menekankan kepada penonton bahwa Upin dan Ipin merupakan sosok anak yang pandai atau pintar. Terbukti bahwa kata 'Pandai' lebih dominan disebutkan dibandingkan kata lainnya.

Gambar: Uncle Atong

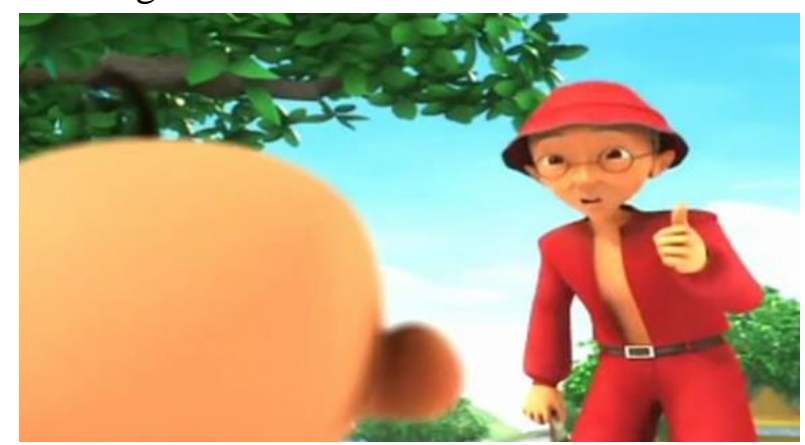

Uncle Atong memuji Upin dan Ipin sebagai anak yang pandai dan dan tindakannya bagus karena kejeliannya melihat tindakan rusuah. Selain itu, Uncle Atong yang mengangkat tangannya dan memberi jempol kepada Upin dan Ipin merupakan pesan non verbal yang memperkuat dan mendukung pesan verbal uncle Atong yakni 'Pandai dan bagus'.

Gambar:Pola asuh Opah (Nenek Upin dan Ipin)

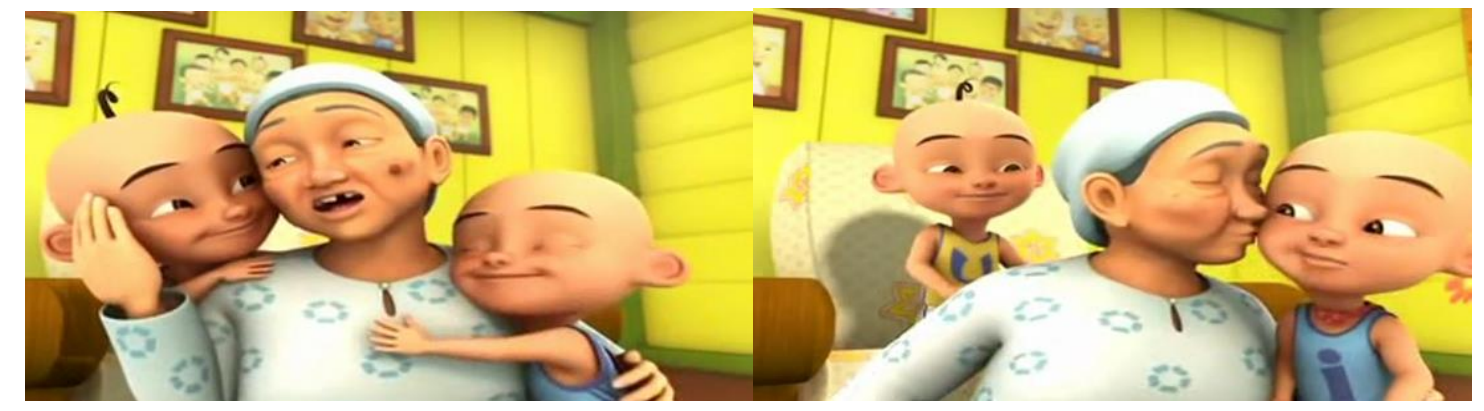

Makna Konotasi

: Opah (Nenek Upin dan Ipin) mengatakan 'elok' kepada Upin dan Ipin. 
Representasi Pesan :Kata elok artinya indah. Maksudnya tindakan yang dilakukan oleh Upin dan Ipin merupakan keindahan perilaku yang dimiliki oleh Upin dan Ipin. Setelah memuji Upin dan Ipin, opah langsung mencium dan memuji kembali dengan kata 'Pandai' kepada Upin dan Ipin (cucu opah) sebagai tanda rasa kasih sayangnya kepada mereka.

Kasih sayang terhadap kedua orang tua disebutkan Allah, antar antara lain dalam QS. Al-Isra:24, sebagai berikut:

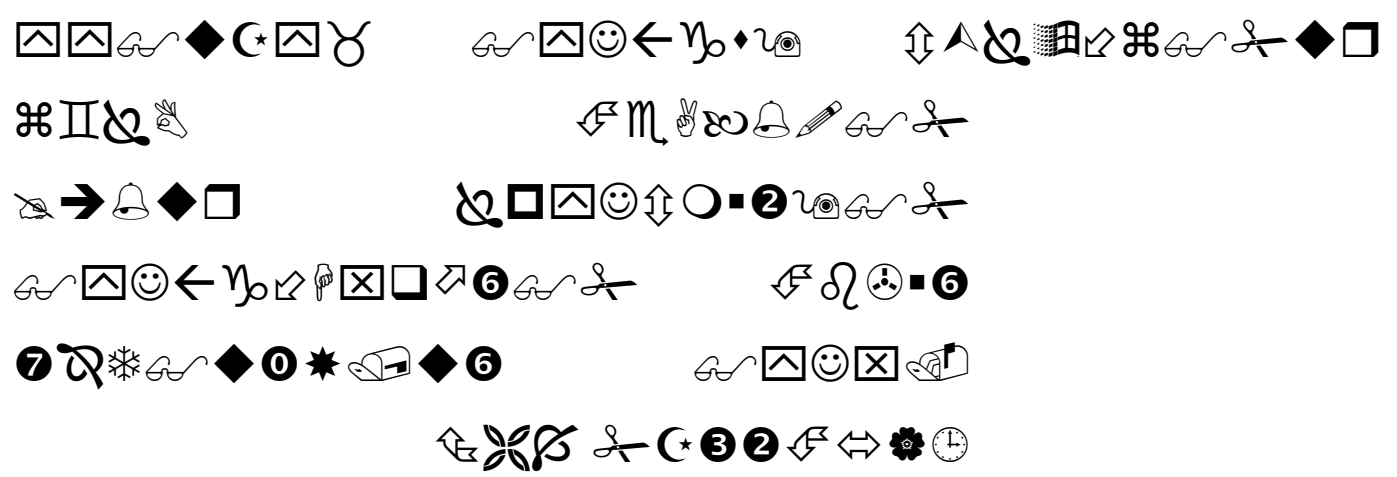

Terjemahan: "Dan rendahkanlah dirimu terhadap dirimu terhadap mereka (kedua orangtuamu) dengan penuh kesayangan dan ucapkanlah: Wahai Tuhanku, kasihilah mereka keduanya, sebagaimana mereka berdua telah mendidik aku waktu kecil". ${ }^{11}$

Ayat tersebut memerintahkan agar anak merendahkan dirinya terhadap kedua orang tuanya dengan didorong oleh rahmat kasih saying kepada keduanya bukan karena takut atau malu dicela orang tidak menghormatinya. Sementara bentuk kasih saying anak terhadap orang tuanya menurut ayat tersebut ialah mendoakan keduanya secara tulus dengan bunyi doa: Wahai Tuhanku yang memelihara dan mendidik aku antara lain dengan menanamkan kasih sayang pada ibu bapaku, kasihanilah keduanya disebabkan keduanya telah melimpahkan kasih

${ }^{11}$ Departemen Agama RI, Al-Qur'an dan Terjemahnya (Surabaya: Terbit Terang), h. 387 
sayang kepadaku, antara lain dengan mendidikku waktu kecil. ${ }^{12}$ Kasih sayang tidak hanya dengan orang tua tetapi dengan guru-guru di sekolah serta temanteman yang kita miliki termasuk makhluk ciptaan Allah lainnya.

Gambar: Episode Isi Masa Lapang
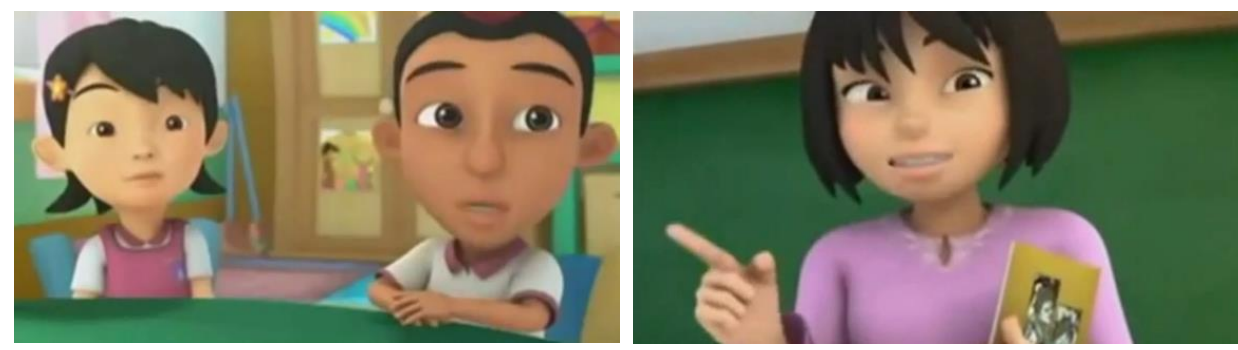

Makna Konotasi

Representasi Pesan
:Ketika Cikguk (ibu guru) menjelaskan tentang pengertian hobi di episode Isi Masa Lapang. Sambil Cikguk menjelaskan, para murid melihat kearah Cikguk. :Menggambarkan bagaimana seorang murid harus memperhatikan, menyimak secara antusias ketika seorang guru menjelaskan. Memang, dalam keseharian proses belajar mengajar para siswa diharuskan lebih memperhatikan gurunya ketika sedang menjelaskan materi pelajaran sehingga para siswa mampu mengerti atau paham terhadap materi pelajaran. Adegan seperti ini memberi peringatan kepada siswa untuk lebih meningkatkan konsentrasinya ketika sedang belajar di kelas,

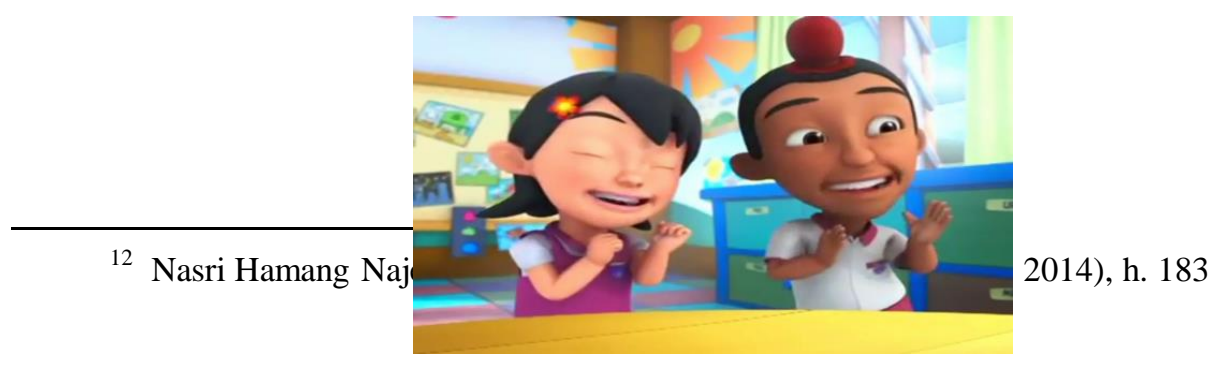




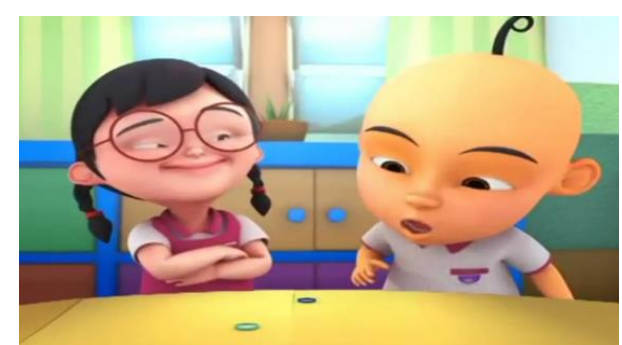

Teman-teman Upin dan Ipin memuji Mei-Mei dengan kata 'Hebat' karena keahliannya dalam memainkan sebuah permainan. Body language (bahasa tubuh) Mei-Mei dengan melipat kedua tangannya di atas dadanya menggambarkan pengakuan atau penguatan atas ungkapan kata 'Hebat' yang dilontarkan kepadanya artinya ia memang merasa hebat.

Gambar: Body Language Upin

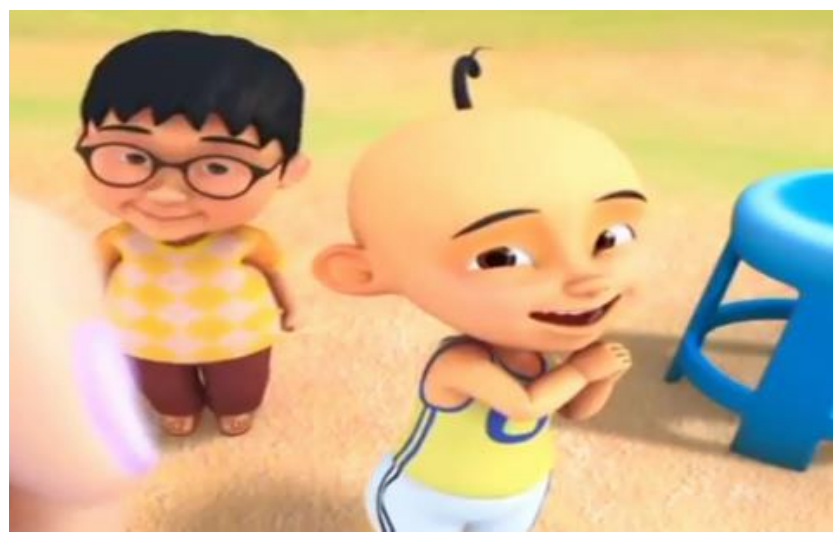

Makna Konotasi : "Kami inikan comel" ungkap Ipin dengan bahasa tubuhnya (body language).

Reprsentasi Pesan : Upin yang memandang dirinya sebagai anak yang comel. Artinya, ia adalah anak yang lucu, imut dan menggemaskan.

Gambar tersebut, merupakan pandangan Upin terhadap dirinya mencerminkan konsep dirinya (self concept). Hal ini sesuai dengan salah satu unsur konsep diri yaitu penilaian diri merupakan pandangan diri terhadap kondisi tubuh kita (bayangan subjektif). Konsep diri yang positif akan dimiliki kalau 
merasa puas (menerima) keadaan fisik diri sendiri. Sebaliknya, kalau merasa tidak puas dan menilai buruk keadaan fisik sendiri maka konsep diri juga negatif atau akan jadi memiliki perasaan rendah diri. ${ }^{13}$ Seperti siswa yang memandang dirinya bodoh, jelek atau tidak cantik sehingga pandagan negatif tentang dirinya akan mengurangi tingkat kepercayaan dirinya.

Kata 'comel' dalam keseharian siswa pun tidak luput dari penerapan dalam keseharian anak-anak. Karena intesitas menonton film ini maka tidak jarang anakanak juga mengimitasi kata comel ini. Apabila mereka melihat sesuatu hal yang lucu, mereka akan juga mengatakan 'comelnyaaa'.

Gambar: Abang Saleh
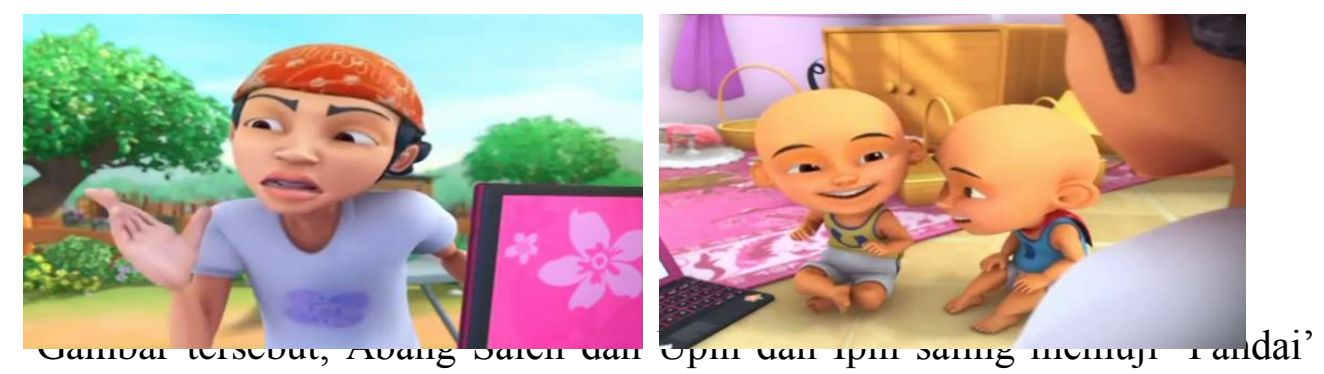

terkait I keahlian mereka masing-masing pada episode usahawan muda. Kata 'Pandai memang penting untuk diberikan kepada anak seperti dalam interaksi guru dan siswa. Hal ini akan membangun self concept yang positif bagi diri siswa.

Self concept atau konsep diri tercipta juga dipengaruhi karena adanya jiwa. Di dalam kitab suci Al-Qur'an berbagai ayatnya menjelaskan tentang jiwa manusia yang meliputi tiga ketegori atau tingkatan:

4.2.2.1 An-Nafs al Ammarah sebagaimana disebutkan dalam QS. Yusuf:53

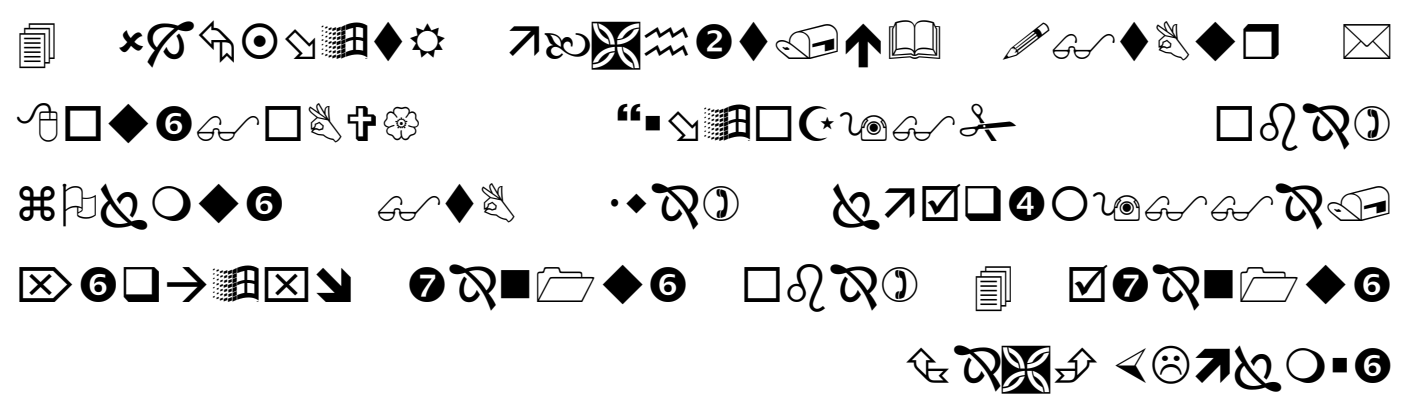

${ }^{13}$ Nina W. Syam, Psikologi Sosial Sebagai Akar Ilmu Komunikasi, h. 57 
圖Terjemahan: Dan Aku tidak membebaskan diriku (dari kesalahan), karena sesungguhnya nafsu itu selalu menyuruh kepada kejahatan, kecuali nafsu yang diberi rahmat oleh Tuhanku. Sesungguhnya Tuhanku Maha Pengampun lagi Maha Penyayang. ${ }^{14}$

Jiwa pada tingkatan ini merupakan keinginan rendah manusia yang cenderung memerintah atau mendorong manusia untuk berbuat keburukan. Pada umumnya tindak keburukan yang dilakukan manusia disebabkan oleh dorongan/keinginan rendah ini. Keinginan rendah manusia jarang menghasilkan tindakan baik. Jiwa kategori ini disebut pula an-nafs al-hayawaniyyah (jiwa/hewani). Manusia dalam pandangan para pakar psikologi memang memiliki nafsu hewani yang disebut jiwa bawah sadar. ${ }^{15}$ Pandangan-pandangan tentang diri yang tidak baik (self concept negative) akan menghasilkan tindakan-tindakan yang dapat merugikan bagi diri sendiri maupun oranglain.

An- Nafs al-Lawwamah seperti disebut dalam QS. Al-Qiyamah: 2

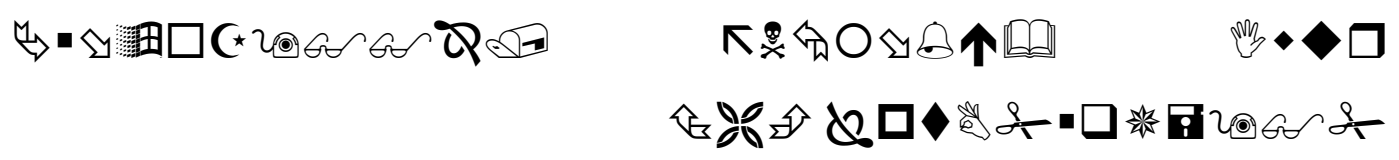

Terjemahan: Dan Aku bersumpah dengan jiwa yang amat menyesali (dirinya sendiri). ${ }^{16}$

Jiwa kategori ini merupakan jiwa yang mencela atau menyalahkan diri sendiri. Jika orang menyimpang dari jalan yang benar yang digariskan Allah dalam agama, seketika timbul rasa penyesalan (an nadm) dalam batinnya. Rasa penyesalan yang jujur atas tindakan yang salah sangat penting dalam rangka kembali (tobat) kepada Allah untuk selalu berada di atas jalan-Nya (fi sabilillah). Jiwa yang memiliki kesadaran atas kesalahan yang pernah diperbuat mempunyai posisi/tingkatan lebih tinggi dari jiwa pada tingkatan pertama. Alasannya, karena jiwa yang sanggup mencela dan menyalahkan diri sendiri memiliki harapan untuk menemukan kembali kebenaran dan mengikutinya. Inilah yang disebut an-nafs alinsaniyyah (jiwa insani) yang dalam pandangan pakar psikologi disebut jiwa ambang sadar.

\footnotetext{
${ }^{14}$ Departemen Agama RI, Al-Qur'an dan Terjemahnya (Surabaya: Terbit Terang), h. 325

${ }^{15}$ Rif'at Syauqi Nawawi, Kepribadian Qur'ani (Jakarta: Sinar Grafika Offset, 2011), h .60

${ }^{16}$ Departemen Agama RI, Al-Qur'an dan Terjemahnya (Surabaya: Terbit Terang), h. 853
} 
An-Nafs al-Muthma'innah (jiwa yang tenang) seperti dalam QS. AlFajr:27

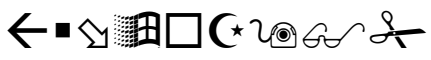

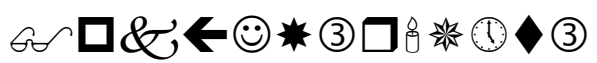

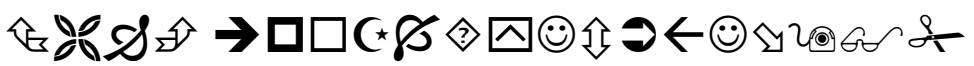

Terjemahan: "Hai jiwa yang tenang".

Jiwa muthma'innah inilah yang merupakan jiwa yang dikecualikan di dalam firman-Nya, inna an-nafsa la'ammarat bi as-su' illa ma rahima rabbi (sesungguhnya nafsu/keinginan rendah itu pastilah memerintah berbuat hal yang buruk kecuali nafsu/jiwa yang dirahmati Tuhanku). Jiwa yang dirahmati Allah adalah jiwa yang beruntung karena Dialah jiwa yang tenang. ${ }^{17}$ Jiwa yang tenang akan selalu berfikir positif terhadap apa yang telah diberikan kepada hamba-Nya.

Orang yang selalu berpikir positif adalah orang yang berjiwa sehat, AlQur'an dengan bijaksana berusaha memerangi jiwa-jiwa jahilia yang negatif dengan firman-Nya:

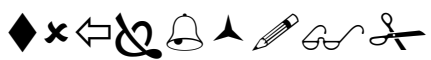

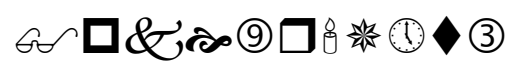

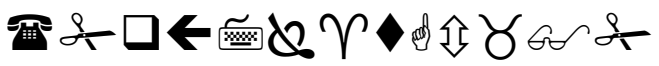

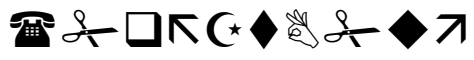

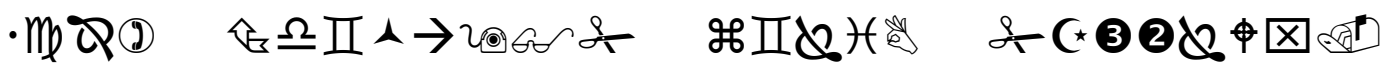

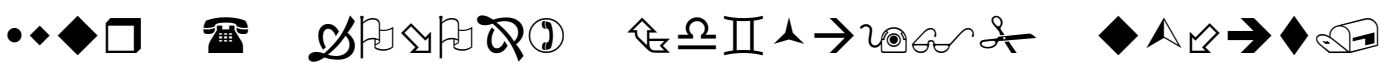

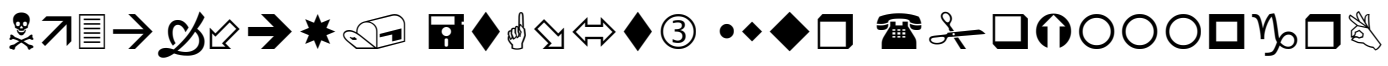

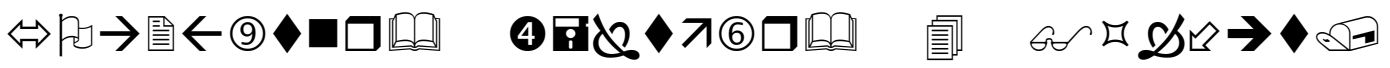

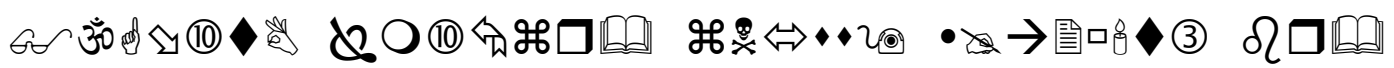

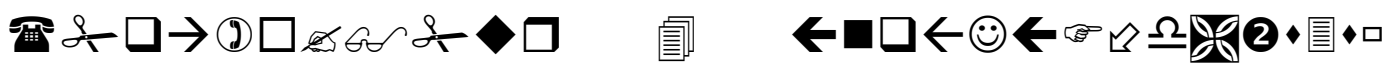

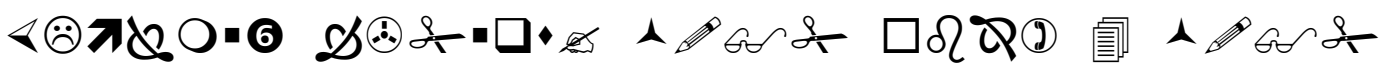
他被全

Terjemahan: "Wahai orang-orang yang beriman, jauhilah banyak prasangka. Sesungguhnya sebagian prasangka itu dosa..." (QS. Al-Hujurat:12).

${ }^{17}$ Rif'at Syauqi Nawawi, Kepribadian Qur'ani (Jakarta: Sinar Grafika Offset, 2011), h .60 
Berpikir positif (positive thinking) merupakan sesuatu hal yang sangat baik. Apalagi jika kita berpikir positif kepada orang lain. Sangat memungkinkan memberi pujian kepada orang lain akan menunjukkan adanya kesadaran dalam membangun konsep diri (self concept) pisitif orang lain.

\section{Pengujian Hipotesis}

Pengujian hipotesis berisi tentang kebenaran hipotesis berdasarkan data yang diperoleh dari sampel penelitian. Dalam hal ini penulis menggunakan teknik statistik untuk mengetahui pengaruh film animasi Upin dan Ipin terhadap self concept siswa, penulis menggunakan rumus pearson product moment sebagai berikut:

Tabel: Variabel X dan Y

\begin{tabular}{|c|c|c|c|c|c|}
\hline NO & $\mathbf{X}$ & $\mathbf{Y}$ & $\mathbf{X}^{\mathbf{2}}$ & $\mathbf{Y}^{\mathbf{2}}$ & $\mathbf{X . Y}$ \\
\hline 1 & 27 & 21 & 729 & 441 & 567 \\
\hline 2 & 26 & 21 & 676 & 441 & 546 \\
\hline 3 & 24 & 28 & 576 & 784 & 672 \\
\hline 4 & 27 & 27 & 729 & 729 & 729 \\
\hline 5 & 26 & 25 & 676 & 625 & 650 \\
\hline 6 & 25 & 26 & 625 & 676 & 650 \\
\hline 7 & 18 & 17 & 324 & 289 & 306 \\
\hline 8 & 26 & 26 & 676 & 676 & 676 \\
\hline 9 & 24 & 24 & 576 & 576 & 576 \\
\hline 10 & 27 & 25 & 729 & 625 & 675 \\
\hline 11 & 28 & 28 & 784 & 784 & 784 \\
\hline 12 & 24 & 28 & 576 & 784 & 672 \\
\hline 13 & 22 & 16 & 484 & 256 & 352 \\
\hline 14 & 24 & 19 & 576 & 361 & 456 \\
\hline 15 & 27 & 26 & 729 & 676 & 702 \\
\hline 16 & 26 & 27 & 676 & 729 & 702 \\
\hline 17 & 25 & 25 & 625 & 625 & 625 \\
\hline
\end{tabular}


273

Hayana, Pengaruh Film Upin dan Ipin terhadap...

\begin{tabular}{|c|c|c|c|c|c|}
18 & 23 & 25 & 529 & 625 & 575 \\
\hline 19 & 19 & 21 & 361 & 441 & 399 \\
\hline 20 & 25 & 25 & 625 & 625 & 625 \\
\hline 21 & 22 & 22 & 484 & 484 & 484 \\
\hline 22 & 22 & 19 & 484 & 361 & 418 \\
\hline 23 & 18 & 20 & 324 & 400 & 360 \\
\hline 24 & 23 & 24 & 529 & 576 & 552 \\
\hline 25 & 27 & 24 & 729 & 576 & 648 \\
\hline 26 & 24 & 24 & 576 & 576 & 576 \\
\hline 27 & 25 & 22 & 625 & 484 & 550 \\
\hline 28 & 27 & 28 & 729 & 784 & 756 \\
\hline 29 & 25 & 22 & 625 & 484 & 550 \\
\hline 30 & 27 & 28 & 729 & 784 & 756 \\
\hline JML & $\mathbf{7 3 3}$ & $\mathbf{7 1 3}$ & $\mathbf{1 8 1 1 5}$ & $\mathbf{1 7 2 7 7}$ & $\mathbf{1 7 5 8 9}$ \\
\hline
\end{tabular}

Keterangan:

Rata-rata variabel $(\Sigma) \overline{\mathrm{X}}=733: 30=24,43$

Rata-rata variabel $(\Sigma) \bar{y}=713: 30=23,76$

$\sum \mathrm{X}^{2}=18115$

$\sum y^{2}=17277$

$\sum \mathrm{X} . \mathrm{Y}=17589$

Selanjutnya dimasukkan dengan rumus korelasi Pearson Product Moment sebagai berikut:

$$
\begin{aligned}
\mathrm{r} x y & =\frac{n \sum x y-\left(\sum x\right)\left(\sum y\right)}{\sqrt{\left[\mathrm{n} \sum x^{2}-\left(\sum x\right)^{2}\right]\left[n \sum y^{2}\right.}-\left(\sum y\right)^{2}} \\
\mathrm{r} & =\frac{(30)(17589)-(733)(713)}{\sqrt{\left[30(18115)-(733)^{2}\right]\left[30(17277)-(713)^{2}\right]}}
\end{aligned}
$$




$$
\begin{aligned}
& r=\frac{527670-522629}{\sqrt{[543450-537289][518310-508369]}} \\
& r=\frac{5041}{\sqrt{[6161][9941]}} \\
& r=\frac{5041}{\sqrt{61246501}} \\
& r=\frac{5041}{\sqrt{7826,0143751465}}=0,644
\end{aligned}
$$

Jadi hubungan antara variabel $\mathrm{X}$ (film animasi Upin dan Ipin) dengan variabel Y (self Concept) sebesar $\mathrm{r}=0,644$. Nilai korelasi sebesar ini tergolong kuat positif sesuai dengan pedoman interpretasi terhadap koefisien korelasi.

Tabel: Pedoman interpretasi terhadap koefisien korelasi

\begin{tabular}{|c|c|}
\hline Interval Koefisien & Tingkat hubungan / Pengaruh \\
\hline $0,00-0,199$ & Sangat Rendah \\
\hline $0,20-0,399$ & Rendah \\
\hline $0,40-0,599$ & Sedang \\
\hline $0,60-0,799$ & Kuat \\
\hline $0,80-0,999$ & Sangat Kuat \\
\hline
\end{tabular}

Berdasarkan tabel interpretasi tersebut, peneliti menyimpulkan bahwa film animasi Upin dan Ipin memiliki hubungan yang kuat terhadap pembentukan self concept siswa di SDN 5 Padanglampe kabupaten Pangkep.

\section{PENUTUP}

\section{Kesimpulan}

Dalam episode perangi rasuah, isi masa lapang, usahawan muda, dan jembatan ilmu terdapat pemaknaan pesan yang mencirikan potensi pembentukan self concept seperti kata pandai dan comel (lucu). 
Terdapat pengaruh yang signifikan antara film animasi Upin dan Ipin terhadap pembentukan self concept siswa di SDN 5 Padanglampe kabupaten Pangkep berada pada kategori hubungan/pengaruh kuat. Hal ini dapat dibuktikan dengan melihat hasil angket yang dibagikan kepada 30 responden. Sedangkan jika dilihat dari uji koefisien determinasinya $\mathrm{r}^{2}=0,644^{2}=0,414736$. Hal ini berarti nilai rata-rata pembentukan self concept siswa $41,47 \%$ ditentukan oleh film animasi Upin dan Ipin yang ditayangkan melalui persamaan regresi $\mathrm{Y}=3,77+$ 0,81 X. Sisanya 58,53\% ditentukan oleh faktor lain.

\section{DAFTAR PUSTAKA}

Alex, Sobur. 2006. Semiotika Komunikasi. Bandung: PT Remaja Rosdakarya

Ardial. 2015. Paradigma dan Model Penelitian Komunikasi. Jakarta: Bumi Aksara

Aziz, Moh. Ali. 2015. Ilmu Dakwah . Jakarta: Prenadamedia Group

Burns, R.B. 1993. Konsep Diri. Jakarta: Arcan

Cangara, Hafied. 2009. Pengantar Ilmu Komunikasi. Jakarta: PT Rajagrafindo

Departemen Agama RI. 2002. Al-Qur'an dan Terjemahnya. Surabaya: Terbit Terang

Kriyantono, Rachmat. 2014. Teori Public Relation Perspektif Barat dan Lokal. Jakarta: Kencana Prenada Media Group

Maspupah. "Jurnal Penelitian Pengaruh Tayangan Kartun Animasi Upin dan Ipin".

Http://repository.uinjkt.ac.id/dspace/bitstream/123456789/2869/1/MASPUP AH-FDK.PDF, (01 Juli 2016)

Morissan. 2013. Teori Komunikasi. Jakarta: Kencana

Muhammad Rizal. 2014. Pengaruh Menonton FILM 5 CM Terhadap Motivasi Kunjungan Wisata ke Guning Sumeru, http://digilib.uinsuka.ac.id/15409/1/10730117_bab-i_iv-atau-v_daftar-pustaka.pdf Oktober 2016) 
Muhtadi, Asep Saiful. 2012. Komunikasi Dakwah. Bandung: PT Remaja Rosdakarya Offset

Noor, Juliansyah. 2014. Metodologi Penelitian: Skripsi, Tesis, Disertasi, dan Karya Ilmiah. Jakarta: Prenadamedia Group

Nurudin. 2007. Pengantar Komunikasi Massa. Jakarta: PT Rajawali Press

Vivi, Fransiska dan Yudarwati, Arum. Konsep Diri serta Faktor- faktor Pembentuk Konsep Diri Berdasarkan Teori Interaksionisme Simbolik. Http://e-journal.uajy.ac.id/5781/1/jurnal.pdf (01 Juli 2016)

Zan Pieter, Herri. Pengantar Komunikasi dan Konseling. Jakarta: Kencana Prenada Media Group. 